\title{
Cardiovascular Risk and Factors Associated to the Health in Hypertensive African Descent People Resident in Quilombola Community
}

Riesgo cardiovascular y factores asociados a la salud en personas afrodescendientes hipertensas residentes en la comunidad Quilombola

Risco cardiovascular e fatores associados à saúde em pessoas afrodescendentes hipertensas residentes em comunidade Quilombola

How to cite this article:

Rosa, Randson Souza; Ribeiro, Ícaro José do Santos; Silva, Jaine Kareny da; Souza, Luiz Humberto Rodrigues; Cruz, Diego Pires; Damasceno, Rudson Oliveira; Souza Júnior, Edison Vitório de; Boery, Rita Narriman Silva de Oliveira. Cardiovascular Risk and Factors Associated to the Health of Hypertensive African Descent People Resident in Quilombola Community. Revista Cuidarte. 2021;12(2):e1165. http://dx.doi.org/10.15649/cuidarte.1165

\section{Revista Cuidarte}

Rev Cuid. May - Ago 2021; 12(2): e1165 doi http://dx.doi.org/10.15649/cuidarte.1165

E-ISSN: 2346-3414

(1) Randson Souza Rosa

(1) Ícaro José do Santos Ribeiro²

(1) Jaine Kareny da Silva ${ }^{3}$

(1) Luiz Humberto Rodrigues Souza ${ }^{4}$

(1) Diego Pires Cruz ${ }^{5}$

(1) Rudson Oliveira Damasceno ${ }^{6}$

(1) Edison Vitório de Souza Junior ${ }^{7}$

(1) Rita Narriman Silva de Oliveira Boery $^{8}$

$1 \mathrm{MSc}$ Nursing and Health, Health Department, Postgraduate Program in Nursing \& Health, State University of Southwest Bahia (UESB), Jequie, BA, Brazil. E-mail: enfrandson@gmail.com Author Correspondence

2 PhD Nursing and Health, Health Department, Postgraduate Program in Nursing \& Health, State University of Southwest Bahia (UESB), Jequie, BA, Brazil. E-mail: icaro.ribeiro29@gmail.com

3 PhD. Professor, Department of Education, State University of Bahia (UNEB), Guanambi, BA, Brazil. E-mail: jainekareny@yahoo.com.br

$4 \mathrm{PhD}$. Professor, Department of Education, State University of Bahia (UNEB), Guanambi, BA, Brazil. E-mail: luizhrsouza21@yahoo.com.br

5 PhD Student Nursing and Health, Health Department, Postgraduate Program in Nursing \& Health, State University of Southwest Bahia (UESB), Jequie, BA, Brazil.E-mail: diego_pcruz@hotmail.com

$6 \mathrm{MSc}$ Nursing and Health, Health Department, Postgraduate Program in Nursing \& Health, State University of Southwest Bahia (UESB), Jequie, BA, Brazil.E-mail: rudsondamasceno@gmail.com

$7 \mathrm{PhD}$ Student Sciences, Graduate Program in Fundamental Nursing, School of Nursing, University of São Paulo (EERP ( USP), Ribeirão Preto, Brazil. E-mail: edison.vitorio@gmail.com

8 PhD. Professor, Health Department, Professor of the postgraduate program in nursing health, State University of Southwest Bahia (UESB), Jequie, BA, Brazil. E-mail: rboery@gmail.com

\section{Abstract}

Introduction: Hypertension is a cardiovascular risk factor of wide magnitude among people of African descent, especially those living in Quilombos. However, little is known about the factors associated with cardiovascular risk in residents of the urban Quilombola community. Objetive: To analyze the cardiovascular risk and health-related factors in the family context of hypertensive Afro-descendants living in an urban Quilombola. Materials and methods: It is a cross-sectional and community-based study carried out from November 2017 to March 2018. The study's population consisted of 303 hypertensive patients enrolled in the family health unit, with ages ranging from 35 to 79 years old, of both genders; and using antihypertensive drugs. The instruments used for data production were: The Primary Arterial Hypertension Questionnaire and the Framingham Risk Score. Results: There was a significant association between cardiovascular risk and cardiovascular disease (CVD) family history $(p<0.011)$, type II diabetes $(p<0.001)$ and overweight and obesity $(p<0.010)$. Conclusion. Research has shown that hypertensive Quilombola people have consistent cardiovascular risk outcomes, especially with CVD family history, type II diabetes, overweight and obesity, schooling and gender with significant associations.

Key words: Cardiovascular Disorders; Risk Factors; African Continental Ancestry Group; Vulnerability in Health.

Received: $24^{\text {th }}$ March 2020

Acepted: $2^{\text {th }}$ Febrary 2021

Published: 24 $4^{\text {th }}$ may 2021 $\square$ *Correspondencia

Randson Souza Rosa

E-mail:enfrandson@gmail.com 


\section{Riesgo cardiovascular y factores asociados a la salud en personas afrodescendientes hipertensas residentes en la comunidad Quilombola}

\section{Resumen}

Introducción: La hipertensión es un factor de riesgo cardiovascular de gran magnitud entre las personas de ascendencia africana, especialmente las que viven en quilombos. Sin embargo, se sabe poco sobre los factores asociados con el riesgo cardiovascular en los residentes de la comunidad urbana Quilombola. Objetivo: Analizar el riesgo cardiovascular y los factores asociados con la salud en el contexto familiar de los descendientes africanos hipertensos que viven en una comunidad urbana de Quilombolas. Material y métodos: Este es un estudio transversal y basado en la comunidad, realizado desde noviembre de 2017 hasta marzo de 2018. La población de estudio consistió en 303 pacientes hipertensos inscritos en la unidad de salud familiar, de edad de 35 a 79 años, ambos sexos; y en el uso medicamentos antihipertensivos. Los instrumentos utilizados para producir los datos fueron: el Cuestionario de Hipertensión en Atención Primaria, la puntuación de riesgo de Framingham. Resultados: Se observó una asociación significativa entre el riesgo cardiovascular y los antecedentes familiares de enfermedad cardiovascular (ECV) $(p<0.011)$, diabetes tipo II $(p<0.001)$ y sobrepeso y obesidad ( $p$ <.010). Conclusión: La investigación mostró que las personas Quilombolas hipertensos tienen resultados consistentes con respecto al riesgo cardiovascular, especialmente con la inclusión de antecedentes familiares de ECV, diabetes tipo II, sobrepeso y obesidad, educación y sexo con asociaciones significativas.

Palabras clave: Enfermedades cardiovasculares; Factores de riesgo; Grupo de ascendencia continental africana; Vulnerabilidad de salud.

\section{Risco cardiovascular e fatores associados à saúde em pessoas afrodescendentes hipertensas residentes em comunidade Quilombola}

\section{Resumo}

Introdução: A hipertensão é um fator de risco cardiovascular de ampla magnitude entre pessoas de ascendência africana, principalmente, as que vivem em Quilombos. No entanto, pouco se sabe sobre os fatores associados ao risco cardiovascular em residentes na comunidade Quilombola urbana. Objetivo: Analisar o risco cardiovascular e fatores associados à saúde no contexto familiar de descendentes africanos hipertensos que vivem em uma comunidade Quilombola urbana. Material e métodos:Trata-se de um estudo censitário de base comunitária, realizado de novembro de 2017 a março de 2018. A população do estudo foi composta por 303 pacientes hipertensos matriculados na unidade de saúde da família, com idades entre 35 e 79 anos, ambos os sexos; e em uso de medicamentos anti-hipertensivos. Os instrumentos utilizados para produzir os dados foram: o Questionário de Hipertensão na Atenção Primária, e o escore de risco de Framingham. Resultados: Foi observada associação significativa entre risco cardiovascular e histórico familiar de doença cardiovascular (DCV) ( $p<0,011)$, diabetes tipo II ( $p<0,001)$ e sobrepeso e obesidade $(p<0,010)$. Conclusão: A pesquisa mostrou que pessoas hipertensas quilombolas apresentam resultados consistentes em relação ao risco cardiovascular, principalmente com a inclusão de histórico familiar de DCV, diabetes tipo II, sobrepeso e obesidade, educação e sexo com associações significativas.

Palavras chave: Doenças cardiovasculares; Fatores de risco; Grupo de ascendência continental africana; Vulnerabilidade à saúde. 


\section{Introduction}

In Brazil, Quilombola populations are conceptualized in the context of ethnic minority groups belonging to the black population', which includes people with black, brown, indigenous and white (uncommon) skin color. They are mostly residents of rural or semi-urban areas, and a minority live in urban areas, where together they make up a representative part of the AfroBrazilian population, and at the same time, are forgotten by the society.

Afro-descendants living in these communities share in their daily living and health conditions, knowledge, attitudes, beliefs, cultures and alternative health practices that are inherited from their ancestors. These facts put them in the spotlight in the health research context, since they live in social vulnerability conditions and, at times, are distant from healthcare service networks, which hinder their access to diagnostic, clinical, therapeutic and health rehabilitation services, thus potentiating chronic illness due to conditions that are sensitive to the promotion, prevention and control of cardiovascular diseases (CVDs).

The complexity related to the etiology of cardiovascular diseases is marked by genetic, social, cultural, economic aspects ${ }^{2}$, of CVD's premature history in the family ${ }^{3}$, behavioral risk factors expressed by unhealthy diet, alcohol and tobacco abuse, physical inactivity, overweight, stress, hypercholesterolemia, Diabetes Mellitus and Systemic Arterial Hypertension (SAH) itself.

It is worth noting that men are affected by CVDs earlier in life when compared to women, and that the skin color/race, in black, brown or white people and included in the age group below 70 years old are considered as factors that increase vulnerability to falling sick due to this chronic deteriorating health ${ }^{5}$.

Studies conducted in the USA show that African-American populations have a higher incidence and risk for premature death due to Coronary Artery Disease (CAD) compared to their general population ${ }^{6-8}$, and attribute such data, especially, to the influence of social determinants. It should be noted that African Americans live under conditions of chronic, family, economic, social and cultural vulnerability, and have the same ancestry origin of the Quilombolas belonging to the Brazilian communities.

Multiethnic studies that have assessed risk in socially vulnerable populations are still incipient, mainly due to studies that have analyzed the influence of social determinants on health in hypertensive quilombolas in urban areas. Understanding this relationship can enable health promotion, prevention of health problems, adequate treatments, changes in inappropriate behaviors, as well as the improvement of harmful health conditions deleterious that affect the system cardiovascular disease, which can cause negative clinical impacts on health and quality of life in the ethnic-racial group under study and in those with similar characteristics.

Multiethnic studies that have assessed risk in socially vulnerable populations are still incipient, mainly due to studies that have analyzed the influence of social determinants on health in hypertensive quilombolas in urban areas. Understanding this relationship can enable health promotion, prevention of health problems, adequate treatments, changes in inappropriate behaviors, as well as the improvement of harmful health conditions deleterious that affect the system cardiovascular disease, which can cause negative clinical impacts on health and quality of life in the ethnic-racial group under study and in those with similar characteristics. 
Therefore, this study's objective was to analyze the cardiovascular risk and the factors associated with the health of hypertensive Afro-descendants resident in an urban Quilombola community.

\section{Materials and Methods}

\section{Study design and period}

It is a cross-sectional, community-based census study carried out between November 2017 and March 2018.

\section{Study population and eligibility criteria}

Based on the total population ( $(\mathrm{N}=483)$, an epidemiological census was carried out in the family history files, belonging to the Family Health Unit (FHU), and the interviewees were organized by census sectors, according to the micro areas existing in the community.

The research adhered to the following inclusion criteria: (1) People living in Barro Preto community; (2) registered at the FHU; (3) between 35 and 79 years old; (4) both genders; (5) diagnosed with hypertension; and (6) on antihypertensive treatment. Exclusion criteria were people with a CVD diagnosis; (2) with physical, mental or emotional impairment; (3) not found at the time of the interview, at different days and times; and (4) did not attend the blood collect stage of the study.

Of the 400 eligible individuals with the potential to participate in the survey, 21 people were not found in their homes, and 4 moved to another address. Thus, 375 hypertensive individuals living in the community households were interviewed, who met the research's inclusion and exclusion criteria. However, 68 were excluded because they did not attend the blood collect, and 4 had incomplete questionnaires, resulting in 303 people for analyzing this study.

\section{Data collection and ethical aspects}

Data collect took place in two stages: clinical evaluation with questionnaire completion, body composition assessment and blood pressure (BP) at the time of the interview in the participants' homes. The other stage corresponded to venous blood collect at the Family Health Unit (FHU), located in the study community.

The instruments used that were validated at the national level were: SAH in Primary Health Care $(\mathrm{PHC})^{9}$ and the Framingham Risk Score, FRS. FRS had consistent and important outcomes for preventing and controlling cardiovascular diseases in a study with African-Americans in the Framingham study ${ }^{10}$. FRS assesses the risk on developing acute myocardial heart attack over an estimated 10 years in individuals who have not undergone coronary events and can classify individuals with low risk (<10\%), intermediate risk (10-20\%), and high risk $(>20 \%)^{11}$.

In the clinical evaluation on body composition, weight, height, BMI and waist circumference the procedures adopted and performed were those in accord to the technical instructions stated 
in the anthropometry manual of the National Health Survey (NHS) ${ }^{12}$. In order to obtain people's body mass (in kilograms/kg), this was measured using a digital bio-impedance scale, Omron branded body control (HBF-514C model), with a maximum capacity of up to $150 \mathrm{~kg}$. Stature (in centimeters, $\mathrm{cm}$ ) was verified through a personal portable Sanny ${ }^{\circledR}$ stadiometer caprice (model ES2060).

Waist circumference (WC) (in centimeters, $\mathrm{cm}$ ) was measured using an inelastic and extensible Sanny ${ }^{\circledR}$ measuring tape (model SN-4010), with WC cut-off points $\geq 102 \mathrm{~cm}$ in men and CC $\geq 88$ $\mathrm{cm}$ in women, according to the criteria of the National Cholesterol Education Program III (NCEP III) ${ }^{13}$.

Body Mass Index, BMI (in $\mathrm{kg} / \mathrm{m}^{2}$ ) was obtained by the cut-off point recommended by the World Health Organization, using the following formula: division of body mass by squared height, $\left(\mathrm{BMI}=\right.$ weight $/$ height $^{2}$ ) considering participants as being overweighed (overweight and obesity) with $\mathrm{BMI} \geq 25 \mathrm{~kg} / \mathrm{m}^{2}$ and eutrophic with $\mathrm{BMI}<25 \mathrm{~kg} / \mathrm{m}^{2,14}$

Blood pressure (BP) was measured using an Omron $^{\circledR}$ digital sphygmomanometer (HEM-7113 model), and the values of systolic (SBP) and diastolic blood pressure (DBP) were obtained according to the recommendations of the VII Brazilian Hypertension Guidelines published by the Brazilian Hypertension Society ${ }^{15}$.

The study was submitted and approved by the Research Ethics Committee of Faculdade Independente do Nordeste - FAINOR, opinion No.: 2.015.327 e CAAE No.: 66705617.2.0000.5578.

\section{Data analysis}

Categorical variables were presented in absolute and relative frequency, and the differences among the groups with and without cardiovascular risk were tested using the chi-square test. Variables that displayed a $\mathrm{p}$ value $<0.2$ were introduced in a multivariate logistic regression model, backward method, looking for the best model fit. Data was analyzed using the Statistical Package for Social Sciences - SPSS for Windows software, version 21.0, with a significance level of $p<0.05$.

\section{Results}

Of the 303 hypertensive individuals living in the Quilombola community who met the study eligibility criteria, mean age was 59.8 years old. $(11,3)$ Cardiovascular risk prevalence (moderate and severe) was $63 \%$ (191). Among the hypertensive patients evaluated with cardiovascular risk, it was more prevalent in the following categories of socio-demographic variables: $52.3 \%$ (113) in women, $57.9 \%$ (106) with less than eight years of schooling, $84.1 \%$ (74) reported being illiterate, $62.2 \%$ (171) were included in the subgroup of non-whites (brown, black and indigenous), $64.6 \%$ (62) lived with relatives and without a partner, of which $62.9 \%$ (139) with economic income less than or equal to one minimum wage, according to the characterization in Table 1. 
Table 1. Socio-demographic characteristics of hypertensive Afro-descendants resident in Quilombola community, according to cardiovascular risk stratification. Jequié, 2018. $(\mathrm{N}=303)$.

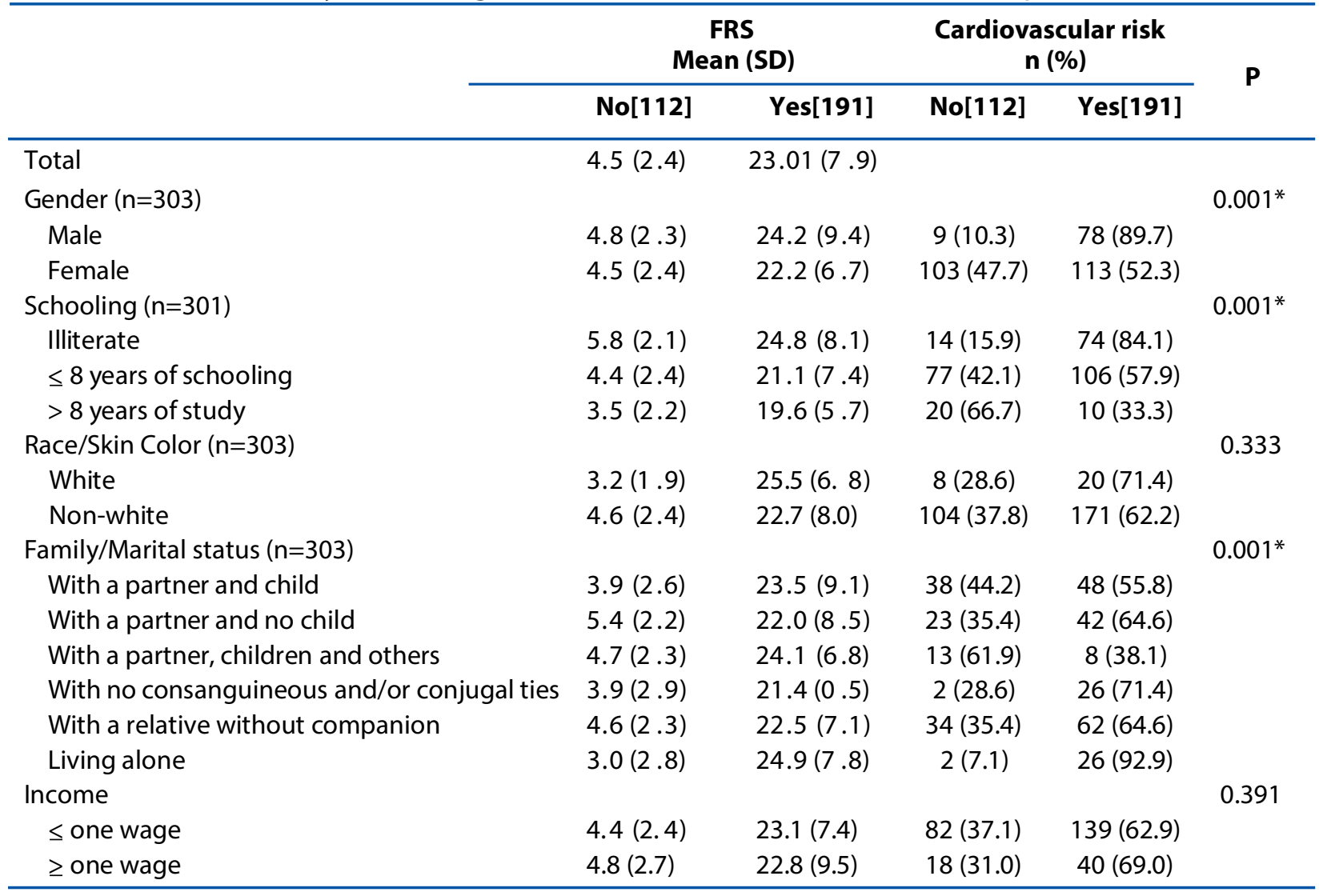

Significant analyses for the cardiovascular risk stratification are described in Table 2, showing $55 \%(\mathrm{~N}=93)$ of hypertensive patients with a CVD family history, $(p<0.011) 87.3 \%(\mathrm{~N}=62)$ with type II diabetes $(p<0.000)$ and $59.3 \%(\mathrm{~N}=137)$ with overweight and obesity $(p<0.010)$. Other attenuating and aggravating data were also noted in the participants, but were not associated with cardiovascular risk, of which $61.5 \%(\mathrm{~N}=169)$ did not smoke, $63.5 \%$

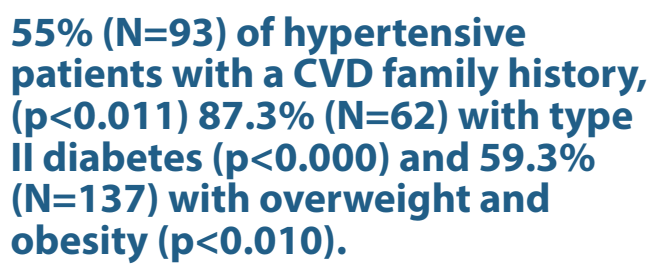

$55 \%(\mathrm{~N}=93)$ of hypertensive patients with a CVD family history, $(p<0.011) 87.3 \%(N=62)$ with type $(\mathrm{N}=137)$ ilabet $(p<000)$ and $59.3 \%$ obesity $(p<0.010)$. $(\mathrm{N}=158)$ did not report using alcohol and $64.1(\mathrm{~N}=98)$ did not practice physical activity (Table 2).

The multivariate analysis started from a saturation model composed of the variables that presented $p<0.2$ in the bivariate analyzes. Using the backward method, two models were built until reaching the statistically most appropriate (model 3) presented below (Table 3). Male gender (OR 0.032 [95\% Cl 0.009-0.18]) and in a family/conjugal situation "With a partner/ children/others" (OR 0.074 [95\% Cl 0.009- 0.637]) have a protective factors. On the other hand, risk factors were pointed out as being illiterate (OR 12.729 [CI95\% 2.890-56.057]) end being affected by Type 2 DM (OR 7.249 [C195\% 2.788-18.846]). 
Table 2. Health profile and life habits of hypertensive Afro-descendants resident in Quilombola community, according to cardiovascular risk stratification. Jequié, 2018. ( $N=303)$

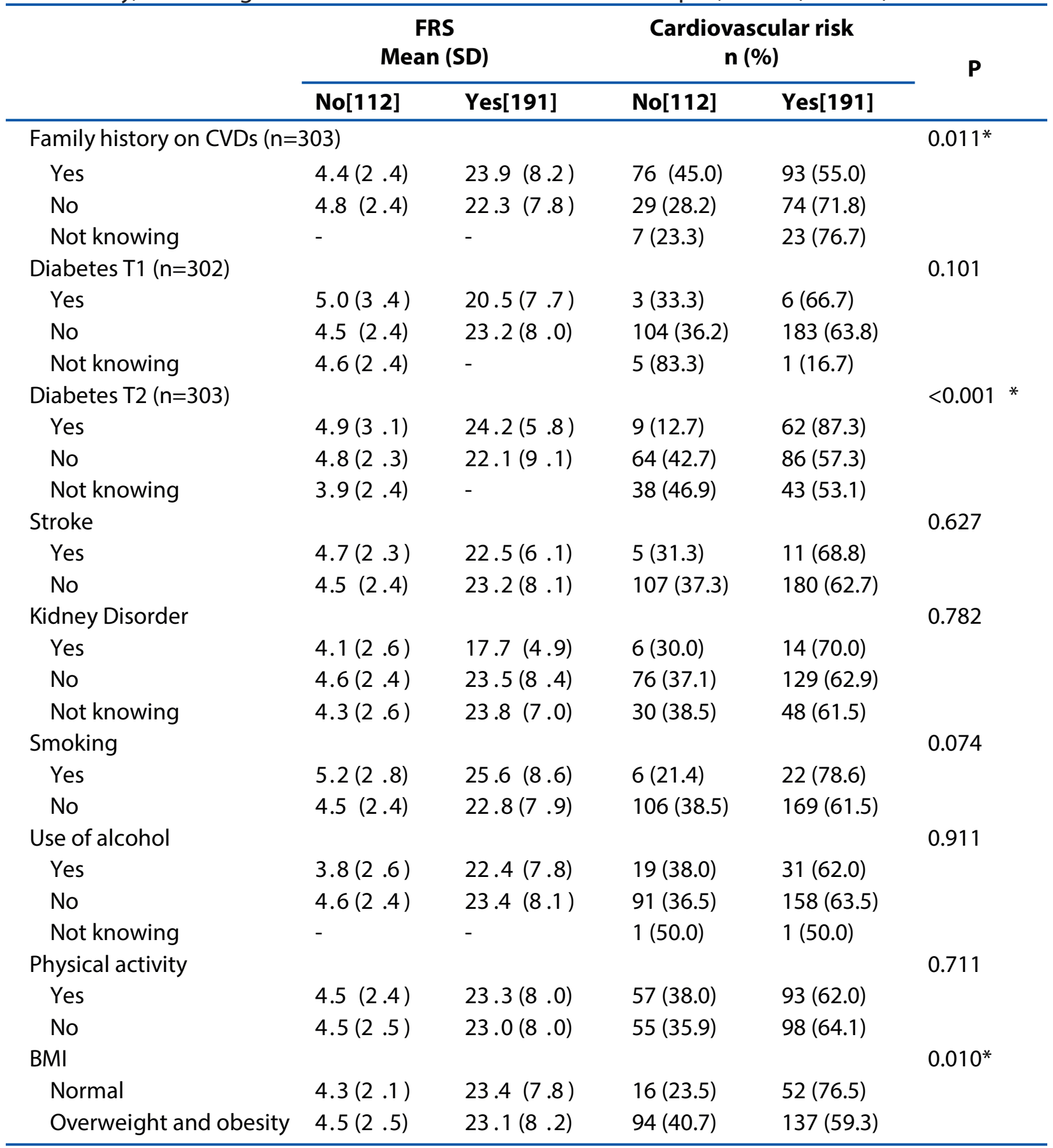

Table 3. Gross and adjusted Odds Ratio (OR) and 95\% confidence interval for the final regression model. Jequié, 2018. $(\mathrm{N}=303)$

\begin{tabular}{lcccc}
\hline & $\begin{array}{c}\text { Crude } \\
\text { OR }\end{array}$ & $\begin{array}{c}\text { [Crude } \\
\mathbf{9 5 \% C l ]}\end{array}$ & $\begin{array}{c}\text { Adjusted } \\
\text { OR }\end{array}$ & $\begin{array}{c}\text { [Adjusted } \\
\mathbf{9 5 \% C l ]}\end{array}$ \\
\hline Male gender & 0.03 & $(0.01-0.13)$ & 0.03 & $(0.01-0.12)$ \\
Living with a partner/children/ others & 0.08 & $(0.01-0.70)$ & 0.07 & $(0.01-0.64)$ \\
Illiterate & 12.09 & $(2.60-56.13)$ & 12.73 & $(2.89-56.06)$ \\
DM2 & 7.38 & $(2.82-19.28)$ & 7.25 & $(2.79-18.85)$ \\
\hline
\end{tabular}

*Hosmer-Lemeshow $(p>0.05)$ 


\section{Discussion}

The increased burden of CVDs in semi-urban communities in developing countries, as in most African countries, shows factors associated with the overlapping prevalence of cardiovascular risk factors, which usually show insidious, an asymptomatic origin and barriers to early diagnosis and risk-related management optimization ${ }^{16}$. It is important to discuss the grouping of health indicators related to excess risk in the context of ethnic health inequalities, in order to elucidate health needs due to inequalities in healthcare accessibility ${ }^{17}$.

Assessing cardiovascular risk in people requires primary identification of multiple associated factors ${ }^{18}$. Very often, they include modifiable and non-modifiable risk factors that can have implications on people's health since that the presence of multiple factors may turn CVD prevention un practical, as well as impair access to healthcare services, such as the performance of a simple laboratory blood test, capable of predicting cardiovascular risk ${ }^{3}$.

The investigation's results showed that (63\%) of the residents in the investigated community were in the strata of moderate and severe cardiovascular risk, highlighting an increase in the prevalence in the female subgroup. In a cross-sectional study on cardiovascular risk among 750 residents in semi-urban communities in southwestern Nigeria, Africa, cardiovascular risk (moderate and severe) was estimated in (22.9\%) of the residents, of whom (70.6\%) corresponded to the female gender, where it can be estimated that about 1 out of 4 had a $10 \%$ to $20 \%$ chance of developing a cardiovascular event over the next ten years ${ }^{16}$. In another study, also conducted in Africa, the average risk for developing CVD in the next 10 years was $3.7 \pm 5.3 \%$ and of moderate and high risk for developing CVD according to FRS, respectively, $11.8 \%$ and $1.9 \%{ }^{19}$.

In a multi-ethnic study referred to as Jackson Heart Study (JHS), the largest CVD cohort study among African-Americans conducted in the United States, it was pointed out that people with cardiovascular risk live in unfavorable neighborhoods and have less family income and education ${ }^{20}$.

Results from an ethnic, sociocultural, cross-sectional study with people living in rural and urban environments in Nigeria, show that income level had no statistically significant relation with the prevalence of the risk factor for CVD ${ }^{21}$. The results are in line with the study under discussion.

A cross-sectional study carried out in Nigeria, with residents of urban areas, inferred that family composition linked to the number of children and dependents causes reasons for concern and stress among married couples, especially, when compared to unmarried and divorced individuals, and evidenced that hypertension, DM, overweight and obesity, arterial wall thickening, large family size/family dependence, and social activity were cardiovascular risks associated with marital status ${ }^{22}$.

In a meta-analysis study, it was found that married people had lower mortality rates due to cardiovascular diseases and risk factors due to the protective effect of marriage, since the spouse encouraged their partner in the search for medical help, medication use and health monitoring, as evidenced in married men, as they most often have better health behaviors than unmarried men $^{23}$. 
The findings regarding marital/family situation may be associated with low family income and the permanence of non-protective life-styles of cardiovascular health being adopted, mainly those who live "with a relative and without a partner", being represented, mainly, by elderly people, widows and retirees and who are sometimes the only providers for the household, where their livelihood is directed only for the subsistence of their family dependents.

In this context, they live in chronic vulnerability conditions, since they cannot afford to finance necessary healthcare such as medical appointments, drug treatment and, often, cannot access primary healthcare services because they do not have the necessary economic standing to pay for their own transport. Consequently, these factors potentiate chronic cardiovascular disease. Those married with children live in conditions similar to the variable "With a relative and without a partner".

The outcomes of the multivariate analysis corroborate a meta-analysis review, which demonstrated the relationship between married ones to divorced or widowed ones and unmarried ones, where divorced, widowed, and unmarried individuals had a high chance of developing CVD (OR 1.42; 95\% Cl 1.00 to 2.01) and consequently, developing a premature death ${ }^{24}$.

In the population-based study conducted in the USA, there were higher mortality rates in single men than in married men after a heart attack event ${ }^{25}$. In the study under discussion, although unrepresentative results have been found, it is to be considered as an important aggravating factor, since single people are responsible for the protagonism of their own care, like preparing their own nutritional diet, experience the work process, often stressful in their daily life and, when they return home, many live locked in their houses, without any distraction or social interaction and, sometimes, when they experience a process of chronic illness, they delay seeking for specialized help, which worsens their health conditions.

The outcomes from assessing the family history of premature coronary artery disease and cardiovascular risk in Multi-Ethnic Study of Atherosclerosis (MESA) ${ }^{26}$ corroborate with this study, since a statistical association $(p<0.001)$ was found and recommendations were made for including the family history of premature CAD in risk assessment scores in individuals at high risk to clinical practice, as well as genetic and environmental factors, since cardiovascular diseases on first-degree relatives (parents), can predict cardiovascular events throughout life ${ }^{27,28}$. This fact reinforces the need for future research on the genetic determinants of cardiovascular risk on the population's health.

Non-protective behaviors of cardiovascular health are the main risk factors (physical inactivity, inadequate diet, alcohol use and smoking) found in the society, given the increase in world prevalence due to urbanization ${ }^{29}$. However, grouping these risk factors increases the chances for people to develop cardiovascular disease, even if presented individually ${ }^{30}$. A study with Africans from the North West Province of South Africa also found no significance correlation between the clinical variables "alcohol use" and "smoking"31.

Although the behavioral variables "smoking" and "alcohol use" were not significantly associated in our study, the findings in this investigation revealed that Quilombola hypertensive people have a lifestyle considered to be protective of cardiovascular health, given that the self- 
reported variables revealed a high prevalence for the non-use of these substances in people with cardiovascular risk. It can be inferred that the uncontrolled/abusive use of these harmful substances to human cardiovascular health, causes clinical impacts on the health-disease process and cardio-deleterious effects on hypertensive people of African descent.

In this study, community research analyses elucidated a significant association between cardiovascular risk and BMI. The association's outcome differs from the findings in the study on excess cardiovascular risk in Jamaican men and women, showing results contrary to this study, since it did not find a significant association between the variables of high CVR/ $\mathrm{BMI}^{32}$. The hypothesis conceived for non-association is that the surveyed Jamaican black people are experiencing a more labor-intensive working process The hypothesis conceived for non-association is that the surveyed Jamaican black people are experiencing a more laborintensive working process based on agriculture that requires more physical effort for their subsistence, while this study's participants live in a typically urban area, where many are unemployed, financially dependent on their relatives, who develop sedentary risk behaviors and with cardio-deleterious effects. based on agriculture that requires more physical effort for their subsistence, while this study's participants live in a typically urban area, where many are unemployed, financially dependent on their relatives, who develop sedentary risk behaviors and with cardio-deleterious effects. The hypothesis can be reinforced since half of those surveyed with cardiovascular risk did not practice physical activity.

In agreement with the study carried out with Jamaican men and women, corroborating data from the study under discussion, since no statistical difference was found regarding physical activity and the risk for 10 years of CVD, according to the FRA, for men and women according to categories in relation to physical activity ${ }^{32}$. The high rates of obesity among African-Americans are related to insulin resistance frequency and to a $50 \%$ increase in DM prevalence ${ }^{33}$. In an African-Americans study, we found cases with high rates of obesity and risk factors for CVDs, with racial and ethnic disparities being attributed to the fact that CVDs in African-Americans were higher in relation to white people ${ }^{34}$.

When evaluating family context through the interview, it was not found that FHU health professionals generally seek to know the hypertensive person's family, with few orienting on lifestyles and treatment for the hypertension condition, nor do they always include relatives in the family treatment.

Family participation throughout the hypertension progression becomes an important clinical care management, which favors changes in lifestyle among people affected by the pathology, and it is important that health professionals include relatives of patients with hypertension in the clinical procedures adopted in order to improve the effectiveness for therapeutic adherence ${ }^{35}$.

It is known that grouping the history of factors associated with cardiovascular risk increases the risk for $\mathrm{CVD}^{36}$. Thus, the multivariate analysis revealed important protective factors and risk for promoting, preventing and controlling chronic cardiovascular disease in hypertensive Quilombolas. The result highlights the following as protection factors: "being male" and in family/conjugal situation "With a partner/children/others". It can be inferred that, for the most part, men, as providers of the family, develop in the daily life of their labor process more physical exertion and vigorous activities and are supported by their relatives, in healthcare need situations, behaving like a protective effect for cardiovascular health and attenuating the cardio-deleterious effects that affect men's cardiovascular system. 
This fact was not evidenced in the variables "being illiterate" and "Type 2 DM" being displayed in the final model as non-protective risk factors for cardiovascular health. The risk of developing cardiovascular risk in 10 years was lower among people with higher schooling levels ${ }^{37}$. The findings regarding the educational variable translate important interpretations for monitoring and evaluating hypertensive people's health, considering that knowledge on this variable can elucidate ethnic racial disparities in access to health, since more educated people understand better their health-care process, seek medical and health services more frequently and, therefore, the risk for cardiovascular disease and cardiovascular effects will be lower. Likewise, it is capable of translating vulnerability conditions in chronic health, considering that the lower the schooling is, the greater is the risk for cardiovascular disease, and the greater will be the interventions for promoting, preventing and controlling cardiovascular diseases, mainly in the perspective of achieving the rehabilitation of cardiovascular health in hypertensive people living in a Quilombola community or who has suffered a cardiovascular event.

Cardiovascular risk evidenced a significant association with DM, corroborating with the findings in the studies ${ }^{38,39}$. DM is closely associated with cardiovascular disease (CVD), since CVD morbidity and mortality are more prevalent in people with diabetes ${ }^{40}$. In men with diabetes, the relative risk for CVD morbidity and mortality ranges from 1 out of 3 men and, among diabetic women, it varies from 2 out of 5 when compared to people with no $\mathrm{DM}^{41}$.

Studies prove that there are disparities in the development of CVDs in diabetic people in relation to gender, the most prevalent mainly being in the course of life of women, since they suffer deleterious influences even in their reproductive age, with the presence of endocrine disorders like the polycystic ovary syndrome and gestational disorders represented by pre-eclampsia, hypertension and diabetes, which, due to premature onset of menopause, are also important risk factors for CVDs, exclusive to women ${ }^{42,43}$.

Diagnosed diabetes is an equivalent risk factor for prior myocardial heart attack. ${ }^{44}$ In a cohort of descendants of the Framingham Heart Study, it was found that African-Americans with higher blood pressure are more likely to develop diabetes than those with normal blood pressure, with an increase in diabetes among hypertensive patients due to the higher adiposity recorded rate, among other cardio-metabolic risk factors ${ }^{45}$.

This study has limitations in the methodological design adopted, since cross-sectional studies do not establish the causal link for the disease. Future research is needed in this population, as it is an urban Afro-Brazilian Quilombola community, living in different contexts when compared to other Quilombola communities, especially because they experience in their daily lives, constant exposure to low health conditions and typically urban human behavior. This reinforces the need for new longitudinal segment research in order to better understand the relationship between cardiovascular risk and new risk factors associated with health determinants in their social, economic and cultural context.

\section{Conclusion}

Research has shown that hypertensive Quilombola people have consistent cardiovascular risk outcomes, especially with CVD family history, Type Il diabetes, overweight and obesity, schooling and gender with significant associations and high prevalence. After the gross and adjusted 
analysis of some variables such as being "male" and "living with a partner/children/others", they behave as protective effects for cardiovascular health. Whereas the variables "schooling" and having "Type II diabetes" showed a cardio-deleterious effect.

Clinical evaluation on the risk in hypertensive Afro-descendants living in a Quilombola community evidenced that the majority is under cardiovascular risk, and revealed conditions for chronic cardiovascular disease in the studied population, since risk conditions are considered subclinical for both hypertensive individuals and health professionals, that is, they were not known to both. For this reason, arterial hypertension can be considered as a cardio-deleterious disease, with and insidious origin, multifactorial and silent progressive course, capable of causing disastrous consequences on human health.

It can be inferred that using the Framingham score has proved to be a health technology with importance for public health and clinical practice, since it shows individual and collective therapeutic efficacy, capable of evaluating cardiovascular risk through population surveys, with cost-effectiveness and proposing therapeutic measures compatible with hypertensive risk conditions, through pharmacological and non-pharmacological therapeutic measures.

In this perspective, classifying people by risk strata can contribute to the clinical management of health care and to the control of chronic cardiovascular disease in people with hypertension who are at high risk of developing an acute cardiovascular event, as well as causing protective clinical impacts on the health and quality of life of people who suffer from chronic hypertension.

As contributions to clinical practice, it becomes necessary to implement multidisciplinary clinical interventions supported by clinical teaching strategies for patients regarding the knowledge of cardiovascular risk and risk factors with cardio-deleterious effects (physical inactivity, inadequate diet, use of alcohol and smoking), as well as diagnostic measures (laboratory tests) like evaluating, monitoring and tracking clinical parameters on the lipid profile, blood pressure control, glycemic control and risk behavior variables, in order to guarantee comprehensive care and cost -effectiveness of health services in populations of minority groups that experience their health-disease process, low socioeconomic conditions and vulnerability of their cardiovascular health conditions.

Conflict of Interest: The authors have no conflicts of interest to declare.

\section{Source of Funding: None}

\section{References}

1. Freitas DA, Caballero AD, Marques AS, Hernández CIV, Antunes SLNO. Saúde e comunidades quilombolas: uma revisão da literatura. Rev. CEFAC 2011;13(5): 937-943. https://doi.org/10.1590/S1516-18462011005000033

2. Paiva SG. Fatores de risco para doenças cardiovasculares em quilombos contemporâneos do Brasil Central: parâmetros demográficos, socioeconômicos, ancestralidade genética e saúde. 2017. 269 f., il. Tese (Doutorado em Biologia Animal) - Universidade de Brasília, Brasília, 2017.

3. Ofori SN, Odia OJ. Risk assessment in the prevention of cardiovascular disease in lowresource settings. Indian Heart J 2016;68(3):391-398. https://doi.org/10.1016/j.ihj.2015.07.004

4. World Health Organization. Información general sobre la Hipertensión en el mundo. Géneve, Suiza: World Health Organization, 2013. 
5. Lotufo PA. Cardiovascular diseases in Brazil: premature mortality, risk factors and priorities for action Comments on the preliminary results from the Brazilian National Health Survey (PNS), 2013. Sao PauloMed J 2015a;133(2):69-72. https://doi.org/10.1590/1516-3180.2015.13320018

6. Ferdinand KC. Coronary artery disease in minority racial and ethnic groups in the United States. Am J Cardiol 2006;97(2A):12A-19A. https://doi.org/10.1016/j.amjcard.2005.11.011

7. Pearson-Stuttard J, Guzman-Castillo M, Penalvo JL, Rehm CD, Afshin A, Danaei G, et al. Modeling future cardiovascular disease mortality in the United States: national trends and racial and ethnic disparities. Circulation 2016;133(10):967-78.

https://doi.org/10.1161/CIRCULATIONAHA.115.019904

8. Mozaffarian D, Benjamin EJ, Go AS, Arnett DK, Blaha MJ, Cushman M, et al. Heart disease and stroke statistics-2016 update a report from the American Heart Association. Circulation 2015;133:e38-e360.

9. Paes NA, Silva CS, Figueiredo TMRM, Cardoso MAA, Lima JO. Satisfação dos usuários hipertensos com os serviços da rede de atenção primária no Brasil: um estudo de validação. Rev Panam Salud Publica. 2014; 36(2): 87-9.

10.Hurley LP, Dickinson LM, Estacio RO, Steiner JF, Havranek EP. Prediction of Cardiovascular Death in Racial/Ethnic Minorities using Framingham Risk Factors. Circ Cardiovadc Qual Outcomes 2010;3(2):181-187. https://doi.org/10.1161/CIRCOUTCOMES.108.831073

11.Xavier HT, Izar MC, Faria Neto JR, Assad MH, Rocha VZ, Sposito AC, Fonseca FA, et al. V. Diretriz Brasileira de Dislipidemias e Prevenção da Aterosclerose. Arq Bras Cardiol 2013;101(Supl 1):1-22. https://doi.org/10.5935/abc.2013S010

12.Brasil. Ministério do Planejamento, Orçamento e Gestão. Instituto Brasileiro de Geografia e Estatística (IBGE). Pesquisa Nacional de Saúde: PNS2013. Manual de Antropometria. Rio de Janeiro, 2013.

13.World Health Organization. Physical status: the use and interpretation of anthropometry. Geneva, 1995. (WHO Technical Report Series, n. 854).

14. National Cholesterol Education Program. Executive summary of the Third Report of the. National Cholesterol Education Program (NCEP) Expert Panel on Detection, Evaluation, and Treatment of High Blood Cholesterol in Adults (Adult Treatment Panel III). JAMA 2001; 285:2486-97. https://doi.org/10.1001/jama.285.19.2486

15.Malachias MVB, Souza WKSB, Plavnik FL, Rodrigues CIS, Brandão AA, Neves MFT, et al. Sociedade Brasileira de Cardiologia; Sociedade Brasileira de Hipertensão; Sociedade Brasileira de Nefrologia. 7 th Brazilian Guideline of Arterial Hypertension. Arq Bras Cardiol 2016;107(Suppl 3):1-83.

16.Oluyombo R, Olamoyegun MA, Olaifa O, Iwuala SO, Babatunde OA. Cardiovascular risk factors in semi-urban communities in southwest Nigeria: patterns and prevalence. J Epidemiol Global Health. 2014;5(2):167-174. https://doi.org/10.1016/j.jegh.2014.07.002

17.Agyemang C, Addo J, Bhopal R, Aikins AG, Stronks K. Cardiovascular disease, diabetes and established risk factors among populations of sub-Saharan African descent in Europe: a literature review. Global Health 2009;5:7. https://doi.org/10.1186/1744-8603-5-7

18.Rosa RS, Macêdo DA, Oliveira BG, Bonfim ES, Casotti C, Prado IP. Evidências para o cuidado de enfermagem na avaliação do Risco Coronariano em Pacientes Hospitalizados. Revista de Pesquisa: Cuidado é Fundamental Online 2016;8(2):4460-4471.

https://doi.org/10.9789/2175-5361.2016.v8i2.4460-4471

19.0guoma VM, Nwose EU, Skinner TC, Richards RS, Digban KA, Onyia IC. Association between metabolic syndrome and 10-year risk of developing cardiovascular disease in a Nigerian population. Int Health. 2016;8(5):354-9. https://doi.org/10.1093/inthealth/ihw013

20.Barber S, Hickson DA, Wang X, Sims M, Nelson C, Diez-Roux AV. Neighborhood disadvantage, poor social conditions, and cardiovascular disease incidence among African American adults in the Jackson Heart Study. American Journal of Public Health 2016;106(12):2219-2226. https://doi.org/10.2105/AJPH.2016.303471 
21.Oguoma VM, Nwose EU, Skinner TC, Digban KA, Onyia IC, Richards RS. Prevalence of cardiovascular disease risk factors among a Nigerian adult population: relationship with income level and accessibility to CVD risks screening. BMC Public Health 2015;15:397. https://doi.org/10.1186/s12889-015-1709-2

22.Anyabolu EN, Okoye IC. Association of Marital Status with Cardiovascular Risks in Urban Dwellers in Nigeria. International Journal of Internal Medicine 2017;6(3):43-48. https://doi.org/10.5923/j.ijim.20170603.01

23.Manfredini R, Giorgi A, Tiseo R, Boari B, Cappadona R, Salmi R, et al. Marital Status, Cardiovascular Diseases, and Cardiovascular Risk Factors: A Review of the Evidence. J Womens Health (Larchmt) 2017;26(6):624-632. https://doi.org/10.1089/jwh.2016.6103

24.Wong CW, Kwok CS, Narain A, Gulati M, Mihalidou AS, Wu P. Marital status and risk of cardiovascular diseases: a systematic review and meta-analysis. Heart. 2018:104(23). https://doi.org/10.1136/heartjnl-2018-313005

25.Chandra V, Szklo M, Goldberg R, Tonascia J. The impact of marital status on survival after an acute myocardial infarction: A population-based study. Am J Epidemiol. 1983;117:320-325. https://doi.org/10.1093/oxfordjournals.aje.a113544

26.Scheuner MT, Setodji CM, Pankow JS, Blumenthal RS, Keeler E. General cardiovascular risk profile identifies advanced coronary artery calcium and is improved by family history: the multiethnic study of atherosclerosis. Circ Cardiovasc Genet. 2010;3:97-105. https://doi.org/10.1161/CIRCGENETICS.109.894527

27.Paynter NP, Chasman DI, Paré G, Buring JE, Cook NR, Miletich JP, et al. Association between a literature-based genetic risk score and cardiovascular events in women. JAMA 2010;303:631-637. https://doi.org/10.1001/jama.2010.119

28.Pandey AK, Blaha MJ, Sharma K, Rivera J, Budoff MJ, Blankstein R, et al. Family history of coronary heart disease and the incidence and progression of coronary artery calcification: Multi-Ethnic Study of Atherosclerosis (MESA). Atherosclerosis 2014;232:369-376. https://doi.org/10.1016/j.atherosclerosis.2013.11.042.

29.Mendis SP, Norrving, B. Global atlas on cardiovascular disease prevention and control. World Health Organization, Geneva, 2011.

30.Kramer KM, Newton KM, Sivarnjan Froelicher ES. Cardiovascular risk factors. Philadelphia: Lippincott, Williams \& Wilkens. 2008;6:753-782.

31.Burger A, Pretorius R, Fourie CMT, Schutte AE. The relationship between cardiovascular risk factors and knowledge of cardiovascular disease in African men in the orth-West Province. Health SA Gesondheid. 2016;21:364 - 371. https://doi.org/10.1016/j.hsag.2016.07.003

32.Tulloch-Reid MK, Younger NO, Ferguson TS, Francis DK, Abdulkadri AO, GordonStrachan GM, et al. Excess Cardiovascular Risk Burden in Jamaican Women Does Not Influence Predicted 10-Year CVD Risk Profiles of Jamaica Adults: An Analysis of the 2007/08 Jamaica Health and Lifestyle Survey. PLoS ONE. 2013;8(6):e66625.

https://doi.org/10.1371/journal.pone.0066625

33.Frieden TR. Centers for Disease Control and Prevention (CDC): Foreword. MMWR Surveill Summ. 2013: 62(Suppl 3):1-2.

34.Taylor HA, Coady SA, Levy D, Walker ER, Vasan RS, Liu J, et al. Relationships of BMI to cardiovascular risk factors differ by ethnicity. Obesity. 2010;18:1638-1645.

https://doi.org/10.1038/oby.2009.407

35.0jo OS, Malomo SO, Sogunle PT. Blood pressure (BP) control and perceived family support in patients with essential hypertension seen at a primary care clinic in Western Nigeria. $J$ Family Med Prim Care. 2016;5(3):569-575. https://doi.org/10.4103/2249-4863.197284

36.Silventoinen K, Hjelmborg J, Möller S, Ripatti S, Skythe A, Tikkanen E, et al. Family aggregation of cardiovascular disease mortality: a register-based prospective study of pooled Nordic twin cohorts. International Journal of Epidemiology 2017;46:1223-1229.

https://doi.org/10.1093/ije/dyx012 
37.Borhanuddin B, Nawi AM, Shah SA, Abdullah N, Zakaria SZS, Kamaruddin MA, et al. 10-Year Cardiovascular Disease Risk Estimation Based on Lipid Profile-Based and BMI-Based Framingham Risk Scores across Multiple Sociodemographic Characteristics: The Malaysian Cohort Project. The Scientific World Journal. 2018:1-8. https://doi.org/10.1155/2018/2979206.

38.D'Agostino RB Sr. Grundy S, Sullivan LM, Wilson P. Validation of the Framingham coronary heart disease prediction scores: results of a multiple ethnic groups investigation. JAMA. 2001;286:180-187. https://doi.org/10.1001/jama.286.2.180

39.Matsha TE, Hassan MS, Kidd M, Erasmus RT. The 30-year cardiovascular risk profile of South Africans with diagnosed diabetes, undiagnosed diabetes, pre-diabetes or normoglycaemia: The Bellville-South Africa Pilot Study. Cardiovasc J Afr 2012;23:5-11. https://doi.org/10.5830/CVJA-2010-087

40.Matheus AS, Tannus LR, Cobas RA, Palma CC, Negrato CA, Gomes MB. Impact of diabetes on cardiovascular disease: an update. Int J Hypertens. 2013;2013:1-15. https://doi.org/10.1155/2013/653789

41.Rivellese AA, Riccardi G, Vaccaro O. Cardiovascular risk in women with diabetes. Nutr Metab Cardiovasc Dis 2010;20:474-480. https://doi.org/10.1016/j.numecd.2010.01.008

42.Appelman Y, Van Rijn BB, Ten Haaf ME, Boersma E, Peters SA. Sex differences in cardiovascular risk factors and disease prevention. Atherosclerosis. 2015;241:211-218. https://doi.org/10.1016/j.atherosclerosis.2015.01.027

43.Behrens I, Basit S, Melbye M, Lykke JA, Wohlfahrt J, Bundgaard $\mathrm{H}$, et al. Risk of postpregnancy hypertension in women with a history of hypertensive disorders of pregnancy: Nationwide cohort study. BMJ 2017;358. https://doi.org/10.1136/bmj.j3078

44.Wannamethee SG, Shaper AG, Whincup PH, Lennon L, Sattar N. Impact of diabetes on cardiovascular disease risk and all-cause mortality in older men: influence of age at onset, diabetes duration, and established and novel risk factors. Arch Intern Med. 2011;171:404-410. https://doi.org/10.1001/archinternmed.2011.2

45.Wei G, Coady S, Goff D, Brancati FL, Levy D, Selvin E, et al. Blood pressure and the risk of developing diabetes in African American and Whites. Diabetes Care 2011;34:873-9.

https://doi.org/10.2337/dc10-1786 